\title{
Amazônia na década de 1970. A fronteira sob o olhar do migrante
}

\section{Amazon in the 1970s. The border under the gaze of the migrant}

Vitale Joanoni Neto ${ }^{1}$

\begin{abstract}
Resumo
Este artigo trata da reocupação da Amazônia Legal, com ênfase no estado de Mato Grosso, durante a ditadura militar no Brasil. A migração para os projetos de colonização e agropecuários foi a estratégia utilizada pelo governo para essa tarefa. Milhares de hectares foram entregues a empresas particulares que, por meio da propaganda, atraíram pequenos proprietários do Sul do país. Essa grande operação o imobiliária visou vender lotes de terras sem, no entanto, dotá-los das condições mínimas para a permanência desses migrantes e suas famílias nos locais. A população existente nessas áreas antes da implantação dos projetos foi ignorada, o que provocou sérios conflitos.
\end{abstract}

Palavras-chave: Migração. Amazônia Legal. Reocupação.

\begin{abstract}
This article deals with the reoccupation of the Amazon, with emphasis on the state of Mato Grosso, during the military dictatorship in Brazil. The migration to the agricultural and colonization projects was the strategy used by the government for this task. Thousands of hectares have been handed over to private companies, through advertising, have attracted small farmers from the South of Brazil. This large estate operations aimed sell land without, however, providing them with the minimum conditions for the permanence of these migrants and their families in the places. The existing population in these areas before the implementation of the projects was ignored, which caused serious conflicts.
\end{abstract}

Keywords: Migration. Legal Amazon. Reoccupation

Artigo recebido em: 22/01/2014

Artigo aprovado para publicação em: 13/02/2014

\section{Introdução}

O acervo do Núcleo de Pesquisa em História (NPH/UFMT) conta com dezenas de entrevistas coletadas por diferentes pesquisas realizadas ao longo dos últimos 13 anos. O foco dessas coletas de dados orais girou em torno da migração de diferentes grupos sociais para a Amazônia Legal brasileira, com os desdobramentos específicos que cada investigação demandava.

\footnotetext{
1 Doutor em História. Docente no Departamento de História da Universidade Federal de Mato Grosso. Coordena o Núcleo de Pesquisa em História e o Grupo de Pesquisa História, Terra e Trabalho. Email: vjneto@uol.com.br
}

Revista Eletrônica da ANPHLAC, ISSN 1679-1061, n. 16, p. 186 -206, Jan./Jul. 2014. http://revista.anphlac.org.br 
Neste artigo, objetivamos analisar a fronteira mato-grossense, fazendo uso do acervo do NPH/UFMT, inclusive dessa documentação oral obtida com os migrados. A reconstrução da vida cotidiana, as relações sociais, políticas, econômicas nesse novo lugar foram investigadas, buscando observar nos relatos orais: como o novo espaço lhes foi apresentado? Como foi seu deslocamento, chegada e reconstrução de suas vidas nesse novo lugar?

O uso das fontes orais nas pesquisas, envolvendo a reocupação da Amazônia Legal brasileira, particularmente em nosso caso, sua parte meridional, tem permitido outro entendimento do processo de reconfiguração espacial e das dinâmicas sociais ampliadas que o envolvem, ou seja, para além do levantamento e análise dos efeitos das políticas de intervenção do Estado Militar sobre a Amazônia, da grande inversão de recursos para atração de empresas que investissem em toda a região em condições privilegiadas, tais fontes nos permitem trazer à luz as memórias subterrâneas, como "parte integrante das culturas minoritárias e dominadas, se opõem à memória oficial, no caso, a memória nacional" (HARRES, in HARRES e JOANONI NETO, 2009, p. 21).

O fato de esse espaço ter sido considerado vazio, o que significou que toda a ocupação pré-existente de diferentes grupos indígenas, garimpeiros, posseiros, comunidades extrativistas e quilombolas foi ignorada para qualquer fim, tornou o avanço dessa nova fronteira do capital muito violento. Antes, porém, de dar prosseguimento ao nosso intento, cabe situar o leitor com informações preliminares sobre esse processo de reocupação.

\section{Sobre o Estado de Mato Grosso no período estudado}

O estado de Mato Grosso constituiu-se dos atuais limites geográficos em 1977, por meio da Lei Complementar N ${ }^{\circ}$. 31, baixada pelo General Presidente Ernesto Geisel, que determinou o desmembramento e a criação do atual Mato Grosso do Sul. As disputas internas e propostas de divisão remetem ao século XIX.

A parte correspondente ao atual Mato Grosso possuía, em 1970, 38 municípios. Em pouco mais de três décadas, esse número saltou para 141, dentre eles 83 não chegavam a dez mil habitantes e 40 estavam com população entre dez e vinte mil habitantes. Apenas 18 estavam acima de 20 mil habitantes (MIRANDA e AMORIM, 2001, p. 9).

Revista Eletrônica da ANPHLAC, ISSN 1679-1061, n. 16, p. 186 -206, Jan./Jul. 2014. http://revista.anphlac.org.br 
Em grande medida, essas novas cidades surgiram diretamente ligadas aos projetos implantados no Estado com forte estímulo do Governo Federal. Isso foi possível primeiramente graças ao Decreto-lei № 1.106, de 16 de junho de 1970, que criou o Programa de Integração Nacional que, em seu artigo segundo, prega:

Art. $2^{\circ}$ A primeira etapa do Programa de Integração Nacional será constituída pela construção imediata das rodovias Transamazônica e Cuiabá-Santarém.

$\S 1^{\circ}$ Será reservada, para colonização e reforma agrária, faixa de terra de até dez quilômetros à esquerda e à direita das novas rodovias para, com os recursos do Programa de Integração Nacional, se executar a ocupação da terra e adequada e produtiva exploração econômica (BRASIL, 1970).

No ano de 1971, o Decreto-lei $N^{\circ} 1.164$, de $1^{\circ}$ de abril, declara:

Art $1^{\text {o }}$ São declaradas indispensáveis à segurança e ao desenvolvimento nacionais, na região da Amazônia Legal, definida no artigo $2^{\circ}$ da Lei $n^{\circ} 5.173$, de 27 de outubro de 1966, as terras devolutas situadas na faixa de cem (100) quilômetros de largura, em cada lado do eixo das seguintes rodovias, já construídas, em construção ou projeto (BRASIL, 1971).

Entre as rodovias incluídas no texto, encontram-se as BR 163, 158 e 364, que cortam o Mato Grosso em três espaços diferentes (Oeste, Norte/Sul e Leste) e a transamazônica, que se constituiu em corredor migratório do Nordeste para a Amazônia e impactou a ocupação do Estado. Essas medidas retiraram das mãos da elite estadual as prerrogativas para dispor desse estoque de terras. Foi nesse espaço, agora sob a responsabilidade da União, que se implantaram os projetos de colonização e agropecuários em condições muito favoráveis para esses empresários, sempre em nome da Segurança Nacional.

Outro elemento importante para entender essa reocupação do estado de Mato Grosso foram os planos e incentivos que disponibilizaram grandes somas de recursos públicos para o setor privado, por meio de agências como a Superintendência para o Desenvolvimento da Amazônia (SUDAM), Superintendência para o Desenvolvimento do Centro Oeste (SUDECO), Banco da Amazônia (BASA), também com a mediação do Instituto de Colonização e Reforma Agrária (INCRA), entre outros.

Em 1971, o governo Federal criou o Programa de Redistribuição de Terras e de Estímulos à Agroindústria do Norte e do Nordeste (PROTERRA), um dos programas aos quais nos referimos acima. Tal medida, entre outras (cf. FERREIRA, 1986: p. 47 e ss.), 
permitiu a aquisição de grandes faixas de terras públicas por empresários que desenvolveram projetos privados de colonização e agropecuários. No Estado de Mato Grosso, dezenas dessas empresas estabeleceram-se por seu extenso território predominantemente visando à venda de lotes de terras para migrantes vindos do Sul e centro-sul do país, no caso das colonizadoras, ou visando à atração de trabalhadores migrantes vindos em sua maioria do Nordeste brasileiro, com baixa qualificação profissional para a dura tarefa de abertura das áreas (desmatamento, limpeza, construção de cercas, etc). Nesse caso, tanto as colonizadoras quanto as agropecuárias interessavam-se por esse público.

Segundo Guimarães Neto (1986: p.142), dados do INCRA, coletados em 1981, mostram que de 101 empresas de colonização autorizadas inicialmente a funcionar no país (inclusive aquelas cujos registros foram cancelados), entre 1970 e 1981, 42\% estavam localizadas em Mato Grosso. De um total de 82 empresas em funcionamento efetivo, 52\% tinham projetos em Mato Grosso; dos 125 projetos autorizados a funcionar, $60 \%$ estavam no Estado. As rodovias federais funcionaram como corredores norteadores da migração. Os maiores projetos privados de colonização aconteceram muito próximos dessas rodovias, $49 \%$ deles (75 projetos), ao longo da CuiabáSantarém. Esta, mais a BR 158 e o complexo $364 / 174$, criados durante o governo militar, tinham a intenção de abrir esses territórios à exploração econômica.

Esse projeto de reocupação passava necessariamente pelo grande empresário, aliado do Governo Militar, beneficiário direto dos recursos disponibilizados. Nas palavras do Ministro do Planejamento de 1973, Reis Veloso, em pronunciamento oficial:

... a necessidade de evitarmos uma ocupação predatória, com um consequente processo de desmatamento, e de promovermos a manutenção do equilíbrio ecológico, nos leva a convidar as grandes empresas a assumirem a tarefa de desenvolver esta região (CASTRO e outros. 1994, p.77)

Esse empresário comprava grandes extensões de terra junto ao INCRA, comprometendo-se a apresentar um plano de ocupação que viabilizasse o estabelecimento de pequenos proprietários em lotes que majoritariamente variavam de 100 a 500 hectares. Os projetos de colonização constavam de planta com a distribuição dos lotes, detalhamento dos subnúcleos e do núcleo urbano. Planejamento executivo para a dotação de infraestrutura viária, de saúde, escolar, administrativa, estudo de solo, Revista Eletrônica da ANPHLAC, ISSN 1679-1061, n. 16, p. 186 -206, Jan./Jul. 2014. http://revista.anphlac.org.br 
regime de chuvas, cobertura vegetal, hidrografia, topografia, com as viabilidades econômicas e as possibilidades de cultivo e previsão de produção e comercialização. Após a apresentação desse complexo documento, o INCRA diplomava a empresa que poderia então iniciar os trabalhos de abertura da área e comercialização da terra. $\mathrm{O}$ órgão deveria fiscalizar a implantação do projeto assim como o Instituto Brasileiro de Desenvolvimento Florestal (IBDF) deveria fiscalizar os percentuais de desmatamento. Ambos se mostraram incapazes para acompanhar uma ação de tamanha envergadura.

Os tamanhos das áreas repassadas para essas empresas variaram muito. Apenas para citar alguns casos, entre os projetos de colonização, a SINOP, ou Sociedade Imobiliária Noroeste do Paraná, recebeu 400 mil hectares para o projeto SINOP. Ela desenvolveu outros projetos no Mato Grosso. A INDECO, Integração, Desenvolvimento e Colonização, recebeu 400 mil hectares para o Projeto Alta Floresta e também desenvolveu outros projetos no Estado. A Cotriguaçu recebeu um milhão de hectares, não conseguiu executar o projeto com o mesmo nome e teve que dividir essa tarefa com outras empresas. Quanto às empresas com projetos pecuários, Casaldáliga, em sua Carta Pastoral de 1971, afirmou:

Até fins de 1970, tinham sido aprovados para os municípios de Barra do Garças e Luciara 66 (sessenta e seis) projetos. De lá para cá muitos outros novos já foram criados, como a BORDON S/A, dos Frigoríficos Bordon, NACIONAL S/A, do Banco Nacional de Minas Gerais, cujo presidente é o ex-ministro das relações Exteriores, Magalhães Pinto, UIRAPURU S/A, do jornalista-latifundiário, David Nasser etc...

As áreas de alguns destes empreendimentos, em território da Prelazia, são absurdas. Destacando-se entre todas: a AGROPECUÁRIA SUIÁMISSU S/A com 695.843 ha. e $351 \mathrm{~m} 2$, que corresponde aproximadamente a 300.00 alqueires, área 5 vezes maior que o Estado da Canabrava e maior também que o Distrito Federal, de propriedades de uma única família paulista: a família Ometto. Destacam-se também a CIA. DE DESENVOLVIMENTO DO ARAGUAIA - " CODEARA", com área de 196.497,19 ha., AGROPASA, com 48.165 ha., URUPIANGA, com 50.468 ha., PORTO VELHO, com 49.994,32 ha., e assim por diante.

Além de serem extensões praticamente inconcebíveis, muitos destes empreendimentos formam grupos somando assim suas já enormes áreas, como é o caso das conhecidas Fazendas Reunidas, "de propriedades do Sr. José Ramos Rodrigues, o "Zezinho das Reunidas", dono da Empresa de ônibus "Reunidas" de "Araçatuba" (O Estado de São Paulo - 9/5/71). Tapiraguai, Sapeva e Brasil Central também formam um grupo. O Sr. Orlando Ometto é também sócio da Tamakavy S/A, etc. (CASALDÁLIGA, 1971, p. 9 - texto mantido como no original).

Revista Eletrônica da ANPHLAC, ISSN 1679-1061, n. 16, p. 186 -206, Jan./Jul. 2014. http://revista.anphlac.org.br 
Como é possível perceber no texto acima, tanto as propriedades destinadas aos projetos de colonização quanto para fins agropecuários possuíam expressivas extensões territoriais, o que nos coloca outro problema. A venda e autorização para o estabelecimento dessas empresas sobre áreas tão grandes partiam do pressuposto de que estavam desocupadas, o que não correspondia às realidades locais. Como já dissemos acima, foram comuns os relatos de conflitos, alguns com mortes, ameaças, expulsão de comunidades inteiras com o uso da força. O acervo da Prelazia de São Félix do Araguaia é rico em documentos que reportam casos desse tipo. Em outras áreas do Estado, sem esse zelo com o registro documental, os relatos dos moradores mais antigos preservam a memória da "limpeza" das terras pela colonizadora, expulsando principalmente a população indígena.

\section{A reocupação do Mato Grosso na voz dos migrantes}

O Governo Militar afirmava ter por objetivo colonizar, entenda-se reocupar, o Norte de Mato Grosso, estimulando o deslocamento de milhares de pessoas para os citados projetos. Esses brasileiros, ao chegarem às novas terras, viam-se na contingência de se submeterem às regras já colocadas ou, na impossibilidade, escolher entre continuar migrando, voltar ao lugar de partida, ou enfrentar o quadro estabelecido na esperança de conseguir seu espaço. Muitos migraram premidos pelas condições, ou a falta delas, em seus locais de moradia. As pressões no campo em todo o país, motivadas por necessidades imediatas (como a seca no Nordeste), ou politicamente organizadas (como as ações dos camponeses sem terra), forçaram os poderes estabelecidos a agir mediando soluções para evitar crises sociais de maior alcance.

As empresas desenvolveram forte campanha publicitária no Sul e Sudeste do país e seu público alvo foram os minifundiários, pequenos produtores capitalizados daquelas regiões que, vendendo dez, por vezes cinco hectares no Paraná, podiam comprar até 200 hectares no Mato Grosso.

Eu vim com a minha família, né, foi mais ou menos no ano de 1985 [...] lá a gente era agricultor, lá a terra muito pequena [...] aí meu pai tinha um sonho de ter um pouco mais de terra aí, meio a contragosto da família [...] viemos todo mundo pra cá, [...] naquela região tinha muito latifúndio, o nosso trecho lá era assim terra lá era pequenininha, era dois alqueires, um alqueire e meio só de café (Depoimento. Juína, $10 / 052001)$.

Revista Eletrônica da ANPHLAC, ISSN 1679-1061, n. 16, p. 186 -206, Jan./Jul. 2014. http://revista.anphlac.org.br 
Relatos como esse são recorrentes entre os migrantes do Sul. Ficaram retidas nas memórias as dificuldades para continuar a viver em pouca terra, os riscos de perdêla para o avanço da grande propriedade mecanizada e a busca por alternativas. Foi esse o contexto no qual a propaganda encontrou terreno fértil. Esses proprietários rurais tinham poucas alternativas no local e mudar, mesmo que sem o pleno consentimento da família, era um meio para que pudessem manter o vínculo com a terra. As alternativas a essa mudança não aparecem como boas em suas memórias.

[...] se eu tivesse ficado lá no Paraná, nós estaríamos muito pior, porque lá era duas coisas ou vai para cidade grande trabalhar de pedreiro que era o caso dele, que ele só sabia fazer esse serviço e uma cidade grande para pobre é só sofrer violência e uma série de coisa, morar em cubículo, [ou] na roça como nós estávamos [...] eu tenho absoluta certeza que aqui foi bom, apesar de muita dificuldade (Depoimento. Juina, 18/09/2000).

Essa avaliação apresentada nos relatos de que foi melhor ter mudado de lugar para não mudar sua condição de lavrador, pequeno proprietário rural, foi em muito auxiliada pela difusão na mídia, rádio e jornal, dos problemas enfrentados por cidades como Curitiba ou Porto Alegre decorrentes da migração campo-cidade e pela propaganda governamental que apresentava a Amazônia como possuidora de terras férteis, local portador de esperanças para os que para ela acorressem. As empresas, interessadas no sucesso dos empreendimentos imobiliários sob seu controle, faziam coro com tais campanhas, levando-as para sindicatos rurais, associações de produtores, comunidades religiosas, jornais, rádios e onde mais pudessem atingir sua clientela potencial.

Ficamos sabendo de Juína assim: no Mato Grosso tem uma cidade que está começando agora, vamos para lá, porque o Paraná já está pronto, já está feito, quem não tem, não tem, quem tem, tem, né. Aí juntou várias pessoas numa kombi, ali dentro tinha um picareta. Na cidade tinha umas pessoas que acompanhava a cada 10 pessoas ele acompanhava até ir para o destino. Então veio aquela kombi e o picareta, prá chegar aqui e comprar. E foi onde que meu pai comprou (Depoimento. Juína, 15/08/2000).

Novamente, nesse relato, aparece fortemente marcada na memória a falta de perspectivas para os moradores dos Estados do Sul do Brasil. A ideia de que tudo já está feito, de que "quem tem, tem" não restando outra possibilidade que não fosse deslocarse, mudar para outros lugares. A figura do picareta ou intermediário, que mostra as Revista Eletrônica da ANPHLAC, ISSN 1679-1061, n. 16, p. 186 -206, Jan./Jul. 2014. http://revista.anphlac.org.br 
terras à venda, nos diz que as empresas estavam perto, prontas a oferecer seus serviços tão logo esses proprietários se mostrassem convencidos da possibilidade de se mudarem. Em muitos casos, vemos nos relatos a preocupação com os filhos, apresentada como razão para o deslocamento, como neste caso:

Que interesse como eu e a veia ia ter por uma colônia de terra / / Eu só vim pra cá pra trazer os filhos e colocá-los (Depoimento. In CASTRO, 1994, p.137).

Essa argumentação, guardada na memória, reforça os elementos expostos acima. O tamanho das propriedades impossibilitava sua reprodução enquanto camponês, o avanço da mecanização exercia uma pressão imobiliária sobre a terra, a falta de perspectivas para os filhos, a esperança de poder ter mais terra sem os problemas que se lhes apresentam no Sul. O modelo de ocupação e desenvolvimento proposto para os Estados do Sul do Brasil, particularmente o Paraná, deu sinais de esgotamento na década de 1970. A taxa de crescimento populacional do Estado entre as décadas de 50 e 70 foi superior a 5,0\% ao ano. A introdução da mecanização, o cultivo de produtos para exportação - como a soja - que exigiam áreas maiores de cultivo; a fragmentação das propriedades com o crescimento das famílias; a extrema valorização da terra $(160 \%$ entre 1980 e 1981) compõem o quadro que provocou grande pressão em toda a região sul do país.

O estudo de Zart (1998: p. 112 e ss.), ao analisar a migração de um grupo de camponeses sem terras de Ronda Alta no estado do Rio Grande do Sul para Lucas do Rio Verde, no médio norte de Mato Grosso, demonstrou que a pressão pela posse da terra no Sul do país culminou por gerar um tipo de organização com força de movimento social e pressionou os poderes constituídos no sentido de romper a estrutura agrária existente no local reivindicando a redistribuição de terras.

Os dados nos mostram que, somente em 1980, cerca de 130 mil agricultores trocaram o campo pela cidade no Rio Grande do Sul. A cidade de Porto Alegre passou de 600 mil habitantes na primeira metade dos anos 70 para 1,2 milhão de habitantes no censo de 1980 com um grande cinturão de pobreza ao seu redor. O mesmo aconteceu com Cascavel (PR) que, com apenas 200 mil habitantes, em 1980 já apontava mais de 13 mil favelados e Curitiba que, para uma população de dois milhões de habitantes em sua região metropolitana em 1980, contava com 300 mil migrantes. “[...] p prefeitura e o estado conseguiram remover 900 barracos em três anos, enquanto o número de Revista Eletrônica da ANPHLAC, ISSN 1679-1061, n. 16, p. 186 -206, Jan./Jul. 2014. http://revista.anphlac.org.br 
favelados cresceu de 17 para 28 mil no mesmo período (SCHAEFER, 1985, p. 23). O mesmo autor fala da existência de cerca de 800 mil agricultores sem terras no Paraná nesse período.

As entidades empresariais e os próprios governos estaduais afirmavam que um dos grandes benefícios das migrações seria o de promover o reagrupamento dos minifúndios, dando condições aos que ficassem de continuar a produzir em uma extensão viável de terra. Entre 1976 e 1978, cerca de 60 mil pequenas propriedades desapareceram no Rio Grande do Sul, incorporadas pelo latifúndio, o que, segundo Schaefer (1985, p. 96), prova que o reagrupamento pretendido de pequenas propriedades rurais não ocorreu. Mesmo com a migração da mão de obra do campo para as cidades maiores, ou para as capitais, a produção, em números absolutos, continuou a crescer. O Paraná bateu recorde de produção de grãos em 1980 (13 milhões de toneladas, $30 \%$ da produção nacional), apesar disso o pequeno produtor estava mais pobre que nos dez anos anteriores.

Foi nesse cenário que a propaganda garantiu terras férteis, falando das possibilidades de desenvolvimento, progresso e lucros. O que a propaganda não falava era que os projetos estavam, em muitos casos, mal cortados por "picadões", trilhas nas quais só se passava a pé, sem nenhuma estrutura de apoio aos colonos como postos de saúde, escolas para as crianças, estradas para o escoamento da produção, conforme constavam dos projetos que lhes eram apresentados durante as negociações para venda dos lotes. Juína é uma dessas cidades que nasceram como resultado dos projetos de colonização. Um dos mostradores de terras que trabalharam nesse projeto, posteriormente, mudou-se para a cidade. Quando entrevistado sobre como viviam os colonos em suas propriedades nessa fase inicial de venda dos lotes, ele relembrou as dificuldades desses primeiros tempos.

[...] quando eles mudavam para esses lugares aí era precário. O colono fazia aqueles ranchinhos de lona de folha de coqueiro até tinha muito aqueles pedacinhos abertos, uns daqui outros dali a gente chegava estava tudo revirado, gente ia conversar com eles ali, a molecada já rodeava a gente, perguntando, molecada toda curiosa, daí tudo cheio de pau, aquelas madeiras pretas sapecadas de fogo, era um horror mesmo. Na época, a gente se virava mesmo com carne de bicho não tinha carne de vaca por aí a fora. Assim iam plantando milho, mandioca e os primeiros que chegavam iam plantando um pouquinho de feijão e depois foram vivendo do custeio próprio do pessoal (Depoimento. Juína, 21/09/2000).

Revista Eletrônica da ANPHLAC, ISSN 1679-1061, n. 16, p. 186 -206, Jan./Jul. 2014. http://revista.anphlac.org.br 
Para bem entender o que significou essa migração para o Mato Grosso, podemos recorrer às pesquisas feitas no norte desse estado entre colonos migrantes, as quais demonstram que os mesmos nasceram, predominantemente, nos estados do Sul e Sudeste, migraram principalmente para o Paraná, de onde saíram para tentar nova vida no Centro-Oeste. Para a maioria absoluta, não foi a primeira migração (SCHAEFER, 1985, p. 99 e ss.). O censo de 1980 revelou o crescimento da migração em direção à Amazônia. Entre 1977 e 1985, 200 mil pessoas se instalaram ao longo da BR-163 (em território mato-grossense). A Capital Cuiabá também sofreu os efeitos do processo migratório. Muitos migrantes, ou por não terem condições de seguir viagem, ou por terem se decepcionado com as áreas de fronteira e voltado, fixaram-se nessa cidade.

Os efeitos podem ser vistos quando comparados os dados dos censos das décadas de 1970, 1980 e 1990.

\begin{tabular}{|c|c|c|c|c|}
\hline População & $\mathbf{1 9 7 0}$ & $\mathbf{1 9 8 0}$ & $\mathbf{1 9 9 1}$ & $\mathbf{2 0 0 0}$ \\
\hline $\begin{array}{c}\text { Natural do } \\
\text { Município }\end{array}$ & 85.512 & 114.196 & 209.590 & 260.668 \\
\hline $\begin{array}{c}\text { Não Natural } \\
\text { do Município }\end{array}$ & 18.348 & 98.784 & 193.224 & 222.677 \\
\hline $\begin{array}{c}\text { Natural do } \\
\text { Estado* }\end{array}$ & 93.137 & 164.302 & 273.795 & 339.212 \\
\hline $\begin{array}{c}\text { Não Natural } \\
\text { do Estado* }\end{array}$ & 7.723 & 48.678 & 129.019 & 144.134 \\
\hline Total $^{\star *}$ & $\mathbf{1 0 0 . 8 6 0}$ & $\mathbf{2 1 2 . 9 8 0}$ & $\mathbf{4 0 2 . 8 1 4}$ & $\mathbf{4 8 3 . 3 4 5}$ \\
\hline
\end{tabular}

Fonte: Perfil Socioeconômico de Cuiabá, vol. III, 2007.

* População natural do Estado e não natural do Estado, residente em Cuiabá.

** Os totais referem-se à população do Município nos anos respectivos. PREFEITURA DE CUIABÁ. Perfil Socioeconômico de Cuiabá. Vol.III. Instituto de Planejamento e Desenvolvimento Urbano (IPDU), Diretoria de Pesquisa e Informação (DPI). Cuiabá: Central de Texto, 2007.

Uma vez fixados em seus lotes, dentro dos projetos, os lavradores passaram a enfrentar as dificuldades dos locais. Além da esperada saudade de seus amigos e parentes, os problemas de deslocamento até os pontos de apoio, distritos ou as cidades nascentes, a falta de assistência médica ou odontológica para a família - vale lembrar aqui que muitas famílias migraram com crianças pequenas e há vários relatos de mulheres grávidas - a inexistência de escolas, ou quando existiam, localizavam-se nos núcleos urbanos, portanto distantes dos lotes, falta de apoio que lhes garantisse transporte em casos de emergência, falta de energia elétrica, mesmo nos distritos ou nas novas cidades, além de riscos desconhecidos, por exemplo, a malária, pouco conhecida pelos lavradores do Sul, chegou a atingir mais de $40 \%$ dessa população migrante nas Revista Eletrônica da ANPHLAC, ISSN 1679-1061, n. 16, p. 186 -206, Jan./Jul. 2014. http://revista.anphlac.org.br 
áreas dos projetos de colonização. 150 pessoas morreram em Rondônia, em 1981, devido a esse mal (SCHAEFER, 1985: p. 141). A tarefa de derrubada das matas também tirou muitas vidas. O uso indevido de armas de fogo, a leishmaniose, a água imprópria que provocava hepatite, gastrenterite, diarreia.

Como é possível perceber, a lista de problemas é longa, todos aparecem em relatos desses migrantes de modos diferentes, já que a memória é nas palavras de Rousso (in FERREIRA e AMADO, 2002, p. 94):

uma reconstrução psíquica e intelectual que acarreta de fato uma representação seletiva do passado, um passado que nunca é aquele do indivíduo somente, mas de um indivíduo inserido num contexto familiar, social, nacional.

Logo, é coletiva, como sugeriu Halbwachs, portanto um elemento importante da construção da identidade individual e de grupo. A partir desses pontos de análise, é possível perceber porque alguns relatos são tão fortes, significativos, e soam plenos de sentido para os membros daquelas cidades. No caso abaixo, uma mulher, que migrou adolescente com a família, rememora a vinda e suas circunstâncias:

[...] fomos facilmente ludibriadas pela empresa colonizadora [...] A compra foi feita por minha mãe, sem ao menos vir olhar as terras [...] Mesmo assim, ela fez negócio no mês de abril do ano de 1983 [...] chegamos em Vila Rica [...] a quase 3800 km de distância da minha terra, do meu lugar. O desespero era grande, casas, pessoas, mosquitos, tudo hostil, tudo diferente [...] que lugar era esse? Que pessoas eram essas? Tão ressequidas, tão queimadas pelo sol? De olhar distante na estrada procurando algo ou alguém que nunca chegava. Que comida era essa que queimava a boca, a garganta? Geladinha, pamonha, pequi? Que língua era essa falada nesse trajeto, que cada vez mais se distanciava de casa, da nossa casa? [...] Ao chegarmos fomos direto procurar nossa mudança, que havia saído na frente uns oito dias, ela estava praticamente jogada numa casa da colonizadora, casa esta sem energia, água, esgoto. O pior foi ficarmos em duas famílias num espaço que mal dava para uma. [...] Ir para roça, impossível. Não havia ponte, isso impossibilitava nossa partida. Ela havia queimado na última temporada de queimas da região. [...] Ficamos todos juntos, espremidos. A primeira noite, quase ninguém dormiu, mosquitos demais, parecia enxame. Revolta demais, que lugar era esse? [...] No outro dia, fomos procurar colégio com transferência em mãos, não consegui vaga [...] A primeira grande perda, um ano inteirinho jogado na sarjeta [...] (Depoimento. Vila Rica, 25/03/2000).

Esse relato foi dado 17 anos depois da chegada ao Mato Grosso e, como sabemos, a memória é refém do tempo presente. Os sucessos ou insucessos alcançados nessas novas terras, as percepções e questionamentos sobre a experiência vivida,

Revista Eletrônica da ANPHLAC, ISSN 1679-1061, n. 16, p. 186 -206, Jan./Jul. 2014. http://revista.anphlac.org.br 
influenciam na presentificação da memória, na sublimação ou destaque dos momentos vividos. Essa família fez parte de um grupo que migrou em condições privilegiadas, ou seja, estava entre aqueles que compraram terras, que vieram com destino certo. Apesar disso, em sua memória ficou gravado o tom de revolta e indignação por se sentir lograda pela colonizadora e pelas perdas materiais com o descuido para com os pertences da família, pessoais com a perda do ano letivo, e familiares, representada pela perda do ano agrícola. Ao dizer da distância entre o Mato Grosso e o "seu" lugar, ela deixa claro que foi impelida a sair e mesmo após tantos anos, esse sentimento está presente em sua memória.

As empresas de colonização não foram capazes de acompanhar a ocupação das terras pelos migrantes aos quais haviam vendido os lotes. Não raro eles viram-se deixados à própria sorte, tendo que se organizar em pequenos grupos para suprir necessidades básicas e reestabelecer laços de sociabilidade nos novos lugares. A religião foi um importante ponto de convergência nesse sentido. Voltaremos a esse tema adiante. Antes, é relevante chamar a atenção para um aspecto componente dessa reocupação. A propaganda atraiu para o Mato Grosso não apenas os migrantes minimamente capitalizados do Sul, mas também muitos lavradores que, por todo o Brasil, desejavam uma oportunidade de acesso a terra ou, ao menos, de trabalho no campo.

A corrida dessas pessoas para as áreas desses projetos deveria ser rigorosamente controlada. Por um lado, interessava sua força de trabalho nas árduas tarefas de derrubada da mata, retirada dos tocos e raízes, construção de cercas, por outro lado, havia o risco de que um grande número dessas pessoas pudesse ensejar a ocupação irregular das terras, interferindo nos interesses das empresas. Inúmeras medidas foram tomadas para controlar essa entrada de trabalhadores nas áreas dos projetos. $\mathrm{Na}$ balsa que levava os colonos ao projeto Alta Floresta, da empresa Integração, Desenvolvimento e Colonização S/A (INDECO), através do rio Teles Pires, "os passageiros de ônibus eram revistados, os dados de sua carteira de identidade anotados por um soldado, e o passageiro tinha que provar a finalidade da sua viagem a Alta Floresta" (SCAEFER, 1985, p.149). No caso do projeto Juína da CODEMAT (Companhia de Desenvolvimento do Estado de Mato Grosso), o único acesso à área era controlado por uma cancela localizada na rodovia AR 1, uma rodovia estadual, que cerceava o livre trânsito. A pessoa só passava pelo controle se trouxesse uma autorização da empresa emitida em um de seus escritórios (Cuiabá/MT ou Vilhena/RO). 
$\mathrm{O}$ posto também era controlado por militares que prestavam serviços à empresa. $\mathrm{E}$ aparece da seguinte forma no depoimento de um antigo funcionário da empresa:

Servia para impedir que entrassem pessoas sem ser colonos, sem querer comprar terras, ou especuladores, ou invasores [...] Um controle de acesso. [...] Só tinha um acesso pra Juína na época, [...] então existia um posto fiscal no $\mathrm{km} 180$ [...] justamente no rio 21 aonde começa o projeto Juína, aí tinha um tenente, tinha uma fiscalização que via se a pessoa que tava chegando, tava autorizada a vir para Juína. [...] Era um pessoal ligado à polícia sim, mas... prestava serviço. [há uma interrupção na gravação] E essa seria a autorização pra você transitar normalmente como se você tivesse quase que um passaporte depois de comprar o lote, antes você tinha que vir com a autorização de acesso, essa carteira de colono ela saía no dia que você assinasse o contrato. Quer dizer, você já tinha que ter vindo aqui, escolhido o lote pra ter essa carteira (Depoimento. Juína, 22/09/2001).

O funcionário explica com clareza a existência do controle de acesso, sua funcionalidade. Em sua memória, ela tem um sentido prático e mesmo alguns aspectos, como o fato de ela restringir a passagem por uma rodovia estadual, ou de que funcionários públicos fossem designados para operá-la, parecem incomodá-lo. Ela se explica por assegurar que só entrassem na área do projeto interessados em comprar lotes, ou os já moradores. Os próprios colonos viram esses controles com maus olhos e criticavam essa presença, além do que uma observação mais cuidada dos projetos mostra, para além da arbitrariedade, a ineficiência desses mecanismos. O projeto Alta Floresta foi alvo de migração de garimpeiros atraídos pela extração manual de ouro que proliferou pela área hoje equivalente aos municípios de Guarantã do Norte, Peixoto de Azevedo, Alta Floresta, Paranaíta, Apiacás, entre outros menores. Como essa ocupação não interessava à empresa colonizadora e interferia em seus negócios, o conflito não tardou e resultou na expulsão dos garimpeiros com um rastro de violência e mortes em número dificilmente calculáveis. (Cf. in SCHAFFAER, 1985 e RIBEIRO, 2008, p.205 e ss.). Em Juína, a entrada de pessoas sem a autorização da empresa foi apoiada pela Igreja Católica local. Elas ocuparam uma área do projeto e chegaram a cerca de quinhentas famílias. Os relatos falam de funcionários vestidos como soldados, tortura em crianças, casas queimadas enquanto todos estavam no trabalho na lavoura, uma situação de tensão que cresceu até a expulsão de todos. Na memória do padre, esse episódio apareceu com um ar grave de denúncia:

A missão recebida me fez parar em Castanheira no dia 22 de dezembro de 1979 [...] me lembro que terminada a missa o homem da

Revista Eletrônica da ANPHLAC, ISSN 1679-1061, n. 16, p. 186 -206, Jan./Jul. 2014. http://revista.anphlac.org.br 
Rural que me trouxe [...] me colocou naquela famigerada casa onde havia um correntão [controle de acesso instalado pela colonizadora para impedir acesso aos projetos]; eu não sabia o que era aquilo. Lá estava uma família, um casal e cinco filhos embaixo da chuva. Eu perguntei: 'Quem são vocês? O que vocês estão esperando?' 'Estamos esperando uma condução que nos leve em Juína, perto do Rio Perdido, porque nós fomos expulsos das nossas terras; nós somos do grupo de posseiros e hoje fomos expulsos'. [...] Perguntei ao motorista 'o que é isso?' Ele me respondeu: 'essa gente é invasora de terra; essa gente tem que sair da terra que não é deles. Sim, mas esta terra é de Deus, que queria dar aquela família, e aos trezentos outros que tinham sido expulsos; e eu não sabia, estava em Vilhena, onde a propaganda era para mandar mais gente para cá, que havia terra MARAVILHOSA, que produzia, como a bíblia diz "Leite e mel". Eu me recusei de subir novamente na rural e pedi que levassem aquela família, e que não a deixassem na chuva, e nem desamparada em Juína. Fui depois conferir. Outra família pobre e humilde, que então começou um barraco na Vila Operária tinha dado um barraco àquela família. [...] $\mathrm{O}$ famigerado Ramon 'Paraguaio' tinha ordem de Juína, ordem de Cuiabá, para impedir a entrega da terra de Deus, que Deus queria dar aos seus filhos que chamou do Sul, que chamou do Norte e Nordeste do Brasil[...]. (Dom Antônio convida Pe. Duílio para dar uma palavra, 1988, p.8).

O padre relata um fato ocorrido há nove anos. É possível perceber os meios usados pelas empresas colonizadoras para manter as suas terras valorizadas e ao mesmo tempo reproduzir uma visão idealizada, sacralizada desses lugares por meio de uma imagem bíblica. Ramon Paraguaio era oficialmente funcionário da empresa, mas, nos muitos relatos colhidos, ele aparece como pessoa perigosa, pistoleiro, credor de muitos serviços prestados a pessoas poderosas. $\mathrm{O}$ aparecimento de seu nome ligado a uma operação de "limpeza" de uma área ou retirada de "invasores" nessa narrativa expõe a memória das lutas travadas entre diferentes grupos e as profundas marcas deixadas. Padre Duílio foi o responsável pela articulação das Comunidades Eclesiais de Base e, na condição de pároco, organizou a Igreja Católica local, para o enfrentamento aos interesses da empresa e dos grandes proprietários, definindo sua atuação naquele campo político conforme uma postura da Igreja Católica denominada Teologia da Libertação. Por isso, nessa narrativa aparecem lado a lado elementos como a ideia da "terra para quem nela trabalha" e do chamado de Deus para que aquelas pessoas ocupassem a terra sob a promessa do "leite e mel".

Revista Eletrônica da ANPHLAC, ISSN 1679-1061, n. 16, p. 186 -206, Jan./Jul. 2014. http://revista.anphlac.org.br 


\section{A migração como peregrinação}

A Igreja Católica estendeu sua presença pelo Mato Grosso, graças aos projetos de colonização que fixaram milhares de pessoas na fronteira que se abria. A fé acompanhou os lavradores em sua migração. As empresas colonizadoras e o governo fizeram farta propaganda da Amazônia, como terra de abundância, fértil, sem geadas (um problema gravíssimo para os colonos do sul). Essa propaganda somou-se à imagem da floresta amazônica, gravada no senso comum, como o eldorado, terra de belezas e de fartura, distante e inóspita.

Essas características somadas, mundo distante e ao mesmo tempo terra de fartura, facilitaram a conexão entre a paisagem e o sagrado. A sacralidade naturalmágica incorporada pela floresta amazônica e a crença do indivíduo culminaram por fixar nela um poder de atração sobre o crente, levando-o a peregrinar em busca da redenção, o que o levou a recriá-la com outro significado, ou seja, esse espaço deixou de ser um local concretamente existente e passou a ser outro, ligado a valores imateriais presentes no imaginário do migrante (FICKELER, 1997, p. 8).

Essa migração do Sul para o Centro-Oeste foi para muitos lavradores uma peregrinação em busca da terra prometida, da solução para seus problemas. Sua chegada ao novo destino foi a chegada ao lugar do sonho, da utopia, constituída dos anseios que carregava: possuir a terra, trabalhar para si, fugir da proletarização. Para o fiel, o sagrado é bastante real e não exige provas para ser crível. Os migrantes que reocuparam o norte de Mato Grosso acreditaram encontrar ali a redenção material e espiritual e isso lhes deu forças para suportarem as dificuldades. Os momentos ruins vividos no início da estada nos locais de chegada foram sublimados. A memória guardou apenas as boas lembranças, ou as guardou como se fossem boas. "Quando o orgulho está em causa, a memória prefere ceder" (JUNG, 197?, p. 36).

Nas áreas de fronteira, a comunidade de vizinhança foi a forma de organização mais comum entre os colonos. Ela reproduziu, em micro escala, a instância pública. A comunidade foi a tutora do bem comum, através dela direcionaram-se os esforços coletivos para a construção e manutenção de escolas, igrejas, lazer e as cobranças pelo cumprimento dos projetos junto às empresas colonizadoras. O que determinou seu surgimento foi, majoritariamente, a extrema carência daquelas pessoas, a ausência do poder público e a proximidade física. Nesse momento, a Igreja Católica se colocou como elo oferecendo o pretexto para a constituição dos grupos. As rezas foram Revista Eletrônica da ANPHLAC, ISSN 1679-1061, n. 16, p. 186 -206, Jan./Jul. 2014. http://revista.anphlac.org.br 
inicialmente usadas para a sua formação, daí seguia-se o trabalho em mutirão para a construção de escolas, o lazer, a convivência. Relações tão necessárias que suplantaram as diferenças de origem, políticas e religiosas. Maranhenses, baianos, mineiros, paulistas, paranaenses, gaúchos, reuniram-se nessas comunidades e estabeleceram metas comuns que, por vezes, contrariavam os interesses e os planos das colonizadoras.

Observando os vários projetos de colonização, notamos a Igreja Católica exercendo diferentes papéis. Em algumas áreas, ela fez os discursos das empresas e governo, em outras, mostrou-se omissa e, em algumas outras, colocou-se ao lado dos migrantes, posseiros, indígenas contra os interesses das empresas. D. Henrique Froehlich veio para o Mato Grosso atuar na Missão Anchieta em Utiariti, em 1956. Foi ordenado Bispo da Prelazia de Diamantino em 1971, ficando posteriormente em Sinop, após a divisão administrativa. Sobre suas relações com as empresas colonizadoras particulares, afirmou:

[...] viria posteriormente a fazer doações generosas às paróquias de Vera, Claudia, e à igreja de Carmem [...] nunca negaram qualquer terreno para as paróquias, para as capelas, para a Cúria Diocesana (uma quadra inteira) e para outras obras sociais. Além disso, deram uma chácara para a construção do Centro Pastoral e mais duas chácaras à Diocese de Sinop, como brinde. [...] O Sr. Ariosto da Riva, que colonizou Alta Floresta, forneceu-nos terrenos para três paróquias e trinta capelas da cidade e grande parte das capelas rurais. Doou ainda áreas para a construção de dois Centros de Pastoral (FROEHLICH, 1999, p. 48).

Esse apoio e generosidade das colonizadoras para com a Igreja, seu Bispo e padres, tinha um preço. Ele pode ser notado na análise da documentação que envolve a área dessa diocese. Nos projetos de colonização particulares Carlinda, Colíder, Nova Canaã do Norte, Paranaíta, Apiacás, Nova Bandeirantes e Terra Nova, bem como no Projeto de Assentamento Braço Sul, a Igreja ou não apareceu de forma significativa nos relatos ou apareceu com dificuldades na organização dos colonos em comunidades católicas, ou ainda, como aliada das empresas colonizadoras.

No Projeto de Assentamento Conjunto (PAC) Peixoto de Azevedo, em Guarantã do Norte, o deslocamento dos colonos foi visto (também) como estratégia de rompimento de sua organização política por reforma agrária, financiamento agrícola e outras reivindicações. A Igreja, o INCRA e a Cooperativa foram importantes instrumentos usados pelo governo federal para reorganizar a vida dos assentados, evitando assim que ressurgissem organizações as instâncias organizativas de seus

Revista Eletrônica da ANPHLAC, ISSN 1679-1061, n. 16, p. 186 -206, Jan./Jul. 2014. http://revista.anphlac.org.br 
lugares de origem, quebradas com seu deslocamento (CASTRO e outros, 2002, p.171 e 217). No Projeto Lucas do Rio Verde, os relatos trouxeram as lembranças de práticas domésticas ou comunitárias de expressão religiosa e ao mesmo tempo a distância para com a igreja. Ao que nos parece, o representante da instituição neste projeto não se preocupou com a proximidade ao cotidiano dos colonos. Referiram-se a ele como "o padre", ele não tem nome, revelando uma aparente relação de indiferença. Alguns relatos afirmaram que o clérigo ignorava sua presença naquele local. Mesmo assim, os colonos não abriam mão da religião na reconstrução de seu espaço.

[...] as dificuldades eram superadas pela união. Era sofrido, mas era divertido. Sofria, mas era gostoso, a gente se unia. Mesmo para rezar a gente não tinha igreja. $\mathrm{O}$ padre nem sabia que a gente tava aqui, então a gente se reunia em cada final de semana numa casa e fazia o culto, fazia novena, era dessa forma que a gente fazia (ZART, 1998, p.148 grifo nosso).

Enfatizamos aqui a presença da Igreja Católica por aparecer como majoritária na documentação coletada, mas, apenas para registro, encontramos outros grupos cristãos presentes no processo de reocupação de Mato Grosso, por exemplo, nos projetos Canarana, Água Boa e Querência, nos quais a presença de Luteranos foi importante. O mentor dos projetos foi o Pastor Norberto Schwantes, à frente da Cooperativa de Colonização 31 de março Ltda., que trouxe colonos do Rio Grande do Sul para o leste de Mato Grosso na primeira metade dos anos 1970. No levantamento documental realizado no Noroeste de Mato Grosso, a presença de denominações evangélicas ou de religiões não cristãs detectadas no período inicial da colonização foi pequena. Essa realidade mudou paulatinamente com o crescimento do núcleo urbano. Entre 1980 e 1996, a população rural cresceu 15,65\% e a urbana, 382\%. Esse crescimento urbano inclui o deslocamento campo/cidade.

Poderíamos ainda tratar aqui do nordeste do estado de Mato Grosso, área da Prelazia de São Félix do Araguaia, sob a administração do Bispo Dom Pedro Casaldáliga. Ali, a Igreja Católica desempenhou um papel importante na defesa das comunidades tradicionais e na resistência contra a implantação arbitrária de projetos agropecuários que, desconsiderando a ocupação muito anterior, recriava esses espaços segundo seus interesses. Uma história rica, com muitos desdobramentos, mas que infelizmente não caberia nesse artigo (Cf. em HARRES e JOANONI NETO, 2009).

Revista Eletrônica da ANPHLAC, ISSN 1679-1061, n. 16, p. 186 -206, Jan./Jul. 2014. http://revista.anphlac.org.br 


\section{Considerações Finais}

A reocupação da Amazônia Legal brasileira, durante o período militar, foi assimilada no discurso oficial a uma reforma agrária que consistiu basicamente em instalar os chamados projetos de colonização nos estados componentes da Amazônia Legal e atrair para eles os pequenos proprietários do Sul do país, prometendo-lhes incentivos e infraestrutura necessários que de fato nunca lhes foram dados. Esses proprietários do Sul do Brasil foram escolhidos por possuírem terras valorizadas, portanto, estavam minimamente capitalizados e em condições de comprar os lotes nos referidos projetos, daí terem sido considerados colonos ideais. Eles foram forçados ou induzidos a se deslocarem para a fronteira mato-grossense, onde se utilizaram da experiência já adquirida para abrir a nova área, sem nenhuma garantia de que permaneceriam nela.

A propaganda oficial foi um dos elementos indutores desse fluxo populacional, oferecendo alternativa para a pressão fundiária existente no Sul do país e colocando as terras supostamente férteis da Amazônia Legal como solução para aqueles pequenos agricultores. Aos outros, agricultores sem terra, meeiros, parceleiros, arrendatários, volantes, o acesso foi bastante, senão completamente, restrito. As práticas dos "correntões", ou dos "cadastros", na entrada dos projetos expôs o caráter desses empreendimentos imobiliários, desnudando o discurso da reforma agrária.

Apenas uma pequena parte desses projetos foi destinada à reocupação pelo colono. Ao menos metade da área dos projetos deveria permanecer preservada como reserva legal, segundo a legislação da época. Esses dispositivos legais, somados às dificuldades do recomeço mais o desconhecimento do solo, clima, regime de chuvas, dificultavam, ou mesmo impediam, o sucesso do pequeno proprietário. A consolidação do projeto de reocupação da Amazônia trouxe a valorização das terras e, novamente, a fragmentação dos lotes, consequentemente, nova onda migratória. No dizer de Guimarães Neto (1986, p.87), “Os colonos foram verdadeiros peões da colonização”. O colono do sul foi transformado em um excluído, foi destituído material e simbolicamente de seu espaço e de seu direito ao espaço. Uma vez na área, as condições postas a essas pessoas não lhes permitiu mais que a reprodução de sua condição de pequeno proprietário e se, a princípio, com um lote maior, bastaram alguns anos para que voltassem à condição original de minifundiários.

Revista Eletrônica da ANPHLAC, ISSN 1679-1061, n. 16, p. 186 -206, Jan./Jul. 2014. http://revista.anphlac.org.br 
Os baixos preços das terras ocultaram a falta de infraestrutura e o verdadeiro caráter dos projetos. Essa operação à qual se atribuía o mérito de fixar o homem a terra, de integração nacional, de ocupação de espaços vazios, que a propaganda se encarregou de consolidar como o equivalente a uma reforma agrária, serviu para desviar as atenções e aliviar as tensões econômicas, sociais e políticas que incidiam sobre o campo em outros estados brasileiros.

Retomando a questão posta no início deste artigo, Angela de Castro Gomes (2012, p. 270) afirma ser a memória capaz de tornar o passado presente: "a memória procura dar unidade ao tempo, atravessando seus 'vazios' e estabelecendo um percurso 'contínuo' cuja coerência unifica e amortece tensões e contradições...”, e isso pode ser observado nos relatos orais apresentados. Uma releitura do vivido feita a partir das idiossincrasias do presente. No entanto, como tocar nessa memória que trata de lugares que nunca desejou deixar, das experiências vividas nos novos lugares, das muitas e diferentes violências sofridas, sem expor as cicatrizes deixadas por essas vivências? Nas memórias desses migrantes, é possível perceber desde dificuldades prosaicas do cotidiano até as marcas mais profundas das violências sofridas, que mesmo os muitos anos passados não atenuam em seus relatos. Os locais nos quais os ritos católicos foram usados para recriar a prática comunitária, posteriormente, serviram para celebrar a memória coletiva daqueles que conseguiram permanecer, não migrar. Essa memória se nos mostra como sendo ora de vitória pessoal, ora de consolo e, em alguns casos, fomentando uma prática de resistência.

Por isso, essas memórias interessam aos historiadores. Sem a pretensão de salvar passados ou dar voz aos silenciados, buscamos indícios e, mediante o cruzamento com outras fontes, revelar com criticidade sua historicidade. Essas memórias, como os outros documentos, não nasceram fontes. São partes de um conjunto deliberado de escolhas que nos possibilitarão um entendimento do presente. E assim, dando futuros aos passados, a História pode dar outros futuros ao presente.

\section{Referências Bibliográficas}

BRASIL. Decreto-lei 1.164 de $1^{\circ}$ de Abril de 1971. Declara indispensáveis à segurança e ao desenvolvimento nacionais terras devolutas situadas na faixa de cem quilômetros de largura em cada lado do eixo de rodovias na Amazônia Legal, e dá outras providências. Disponível em http://www.planalto.gov.br/ccivil_03/decretolei/Del1164.htm. Acesso em 12/12/2013.

Revista Eletrônica da ANPHLAC, ISSN 1679-1061, n. 16, p. 186 -206, Jan./Jul. 2014. http://revista.anphlac.org.br 
BRASIL. Decreto-lei $n^{\circ} 1.106$, de 16 de junho de 1970. Cria o Programa de Integração Nacional, altera a legislação do impôsto de renda das pessoas jurídicas na parte referente a incentivos fiscais e dá outras providências. Disponível em http://www.planalto.gov.br/ccivil_03/decreto-lei/1965-1988/Del1106.htm. Acesso em $\underline{12 / 12 / 2013 .}$

CASALDÁliGA, Pedro. Uma Igreja da Amazônia em conflito com o latifúndio e a marginalização social. São Félix, 10 out. 1971. Disponível em http://www.servicioskoinonia.org/Casaldaliga/cartas/1971CartaPastoral.pdf. Acesso em 16 de dezembro de 2013.

CASTRO, Maria I. e GALETTI, Lylia da S.G. Um histórico do uso da biodiversidade em Mato Grosso. In: CASTRO, Carlos, F. de Abreu. Diagnóstico do setor florestal em Mato Grosso. Brasília: IBAMA/ITTO/FUNATURA, 1994.

CASTRO, Sueli Pereira; BARROZO, João Carlos; COVEZZI, Marinete e PRETI, Oreste. A colonização oficial em Mato Grosso: A nata e a borra da sociedade. Cuiabá: EdUFMT, 1994.

FERREIRA, Eudson de Castro. Posse e Propriedade territorial: a luta pela terra em Mato Grosso. Campinas: Ed. da UNICAMP, 1986.

FERREIRA, Marieta M. e AMADO, Janaina. Usos e abusos da História Oral. Rio de Janeiro: FGV, 2002.

FICKELER, Paul. Questões fundamentais na geografia da religião. Espaço e Cultura. Rio de Janeiro: UERJ, janeiro/junho de 1999, nº7, p. 7-35.

FROEHLICH, D. Henrique. O bispo da floresta. Autobiografia. Ceilândia: Idea Editora, 1999.

GALETTI, Lylia S. Guedes. O poder das imagens: o lugar de Mato Grosso no mapa da civilização. In: SILVA, Luiz Sérgio Duarte da (org.). Relações cidade Campo: Fronteiras. Goiânia: Ed. UFG, 2000.

GOMES, Angela de Castro. História e Memória: ensino de História e memória histórica Nacional. In: SOUZA, Bertulino J. e CÂMARA, Helder C. (Orgs.). Imaginário. Novos desafios, novas epistemologias. Coimbra: CEIDA, 2012.

GUIMARÃES NETO, Regina Beatriz. A lenda do ouro verde - A colonização em Alta Floresta/Mato Grosso. Campinas, 1986. 177 p. Dissertação (Mestrado em História) Instituto de Filosofia e Ciências Humanas da UNICAMP.

GUIMARÃES NETO, Regina. Historiografia, diversidade e historia oral: questões metodológicas. In: LAVERDI, R.; FROTSCHER, M.; DUARTE, G.R.; MONTYSUMA, M.F.F.e MONTENEGRO, A.T. (Orgs.). História Oral, desigualdades e diferenças. Recife: UFPE/UFSC, 2012.

Revista Eletrônica da ANPHLAC, ISSN 1679-1061, n. 16, p. 186 -206, Jan./Jul. 2014. http://revista.anphlac.org.br 
HARRES, Marluza Marques e JOANONI NETO, Vitale (Orgs.). História, Terra e Trabalho em Mato Grosso. Ensaios Teóricos e Resultados de Pesquisas. São Leopoldo/Cuiabá: Oikos/EdUFMT, 2009.

JUNG, Carl G. (Org.). O homem e seus símbolos. Rio de Janeiro: Nova Fronteira, s/d. MIRANDA L. e AMORIM.L. Mato Grosso: Atlas geográfico. Cuiabá: Entrelinhas, 2000.

MOUTINHO, Joaquim Ferreira. Notícia sobre a província de Matto Grosso seguida d'um roteiro de viagem da sua capital a São Paulo. São Paulo: Typographia de Henrique Schroeder, 1869.

OLIVEIRA, João Mariano de. A esperança vem na frente: contribuição ao estudo da pequena produção em Mato Grosso, o caso Sinop. São Paulo, 1983. 144p. Dissertação (Mestrado em Geografia) - Departamento de Geografia da Faculdade de Filosofia, Letras e Ciências Humanas da Universidade de São Paulo.

PREFEITURA DE CUIABÁ. Perfil Socioeconômico de Cuiabá. Vol.III. Instituto de Planejamento e Desenvolvimento Urbano (IPDU), Diretoria de Pesquisa e Informação (DPI). Cuiabá: Central de Texto, 2007.

RIBEIRO, José Donizete. Colonização e garimpos: expropriação e violência no Norte de Mato Grosso. In: BARROZO, João Carlos (Org.) Mato Grosso. Do sonho à utopia da terra. Cuiabá: Carlini \& Caniato/EdUFMT, 2008.

SCHAEFER, José Renato. As migrações Rurais e implicações pastorais. Um estudo das migrações campo-campo do sul do país em direção ao norte do Mato Grosso. São Paulo: Loyola, 1985.

SCHERER-WARREN e KRISCHKE (org.). Uma revolução no cotidiano? São Paulo: Brasiliense, 1987.

ZART, Laudemir Luiz. Desencanto na nova terra. Assentamento no município de Lucas do Rio Verde - MT na década de 80. Florianópolis, 1998. 189p. Dissertação (Mestrado em Sociologia Política) - Programa de Pós-Graduação em Sociologia Política da Universidade Federal de Santa Catarina.

Os Depoimentos orais foram obtidos em viagens a campo nas datas especificadas abaixo. Por razões internas à pesquisa, seus protagonistas seguem não identificados:

Juína, 15 ago. 2000; 18 set. 2000; 21 set. 2000; 22 set. 2000; 10 maio 2001; 31 maio 2001; e Vila Rica, 25 mar. 2000.

Revista Eletrônica da ANPHLAC, ISSN 1679-1061, n. 16, p. 186 -206, Jan./Jul. 2014. http://revista.anphlac.org.br 